\title{
Effect of Maternal Malnutrition on Matrix Cell Proliferation in the Cerebrum of Mouse Embryo: an Autoradiographic Study
}

\author{
M. SHIMADA, ${ }^{(34)}$ T. YAMANO, T. NAKAMURA, Y. MORIKAWA, AND T. KUSUNOKI \\ Department of Pediatrics, Shiga Medical College, Seta, Otsu-shi, and Department of Pediatrics, Kyoto Prefectural \\ University of Medicine, Kyoto, Japan
}

\begin{abstract}
Summary
Thirty pregnant mice were undernourished by providing low protein diets (PM) or providing approximately one-third their normal diets (PCM) for 9 days from the 8th to the 16th day of gestation. Another 15 pregnant mice, which were fed a normal diet, served as the control. On the 16th day of gestation, all animals were injected with a single dose of $\left[{ }^{3} \mathrm{H}\right]$ thymidine and were killed one by one at 1- or 2-hr intervals.

Mean litter size was statistically insignificant between the control group and two malnourished groups. There was, however, a significant difference in mean body weight between the control group and two malnourished groups $(P<0.005)$. The cerebral cortex at this stage of development consisted of three different layers, i.e., the cortical plate, the migratory zone, and the matrix layer. The width of the cortical plate of the malnourished embryos was significantly smaller $(P<0.001)$. There was, however, no significant difference in width of the migratory zone between the control and the malnourished groups. The width of the matrix layer in $P M$ was significantly smaller $(P<0.001)$, but that of PCM showed no significant difference from the control $(P>0.1)$.

Coronal section of the brains of the embryos were processed for autoradiography. Labeled cells were found almost exclusively at the matrix layer surrounding the lateral ventricels. Labeling index counted in the matrix layer after 1 or $2 \mathrm{hr}$ of $\left[{ }^{3} \mathrm{H}\right.$ ]thymidine injection indicated that more than $30 \%$ of the cells in this layer were always synthesizing DNA in each group of embryos. The generation times of the matrix cell, precursor of the neurons, in the matrix layer were approximately $18.5 \mathrm{hr}$ in the control and $21.5 \mathrm{hr}$ and $21.8 \mathrm{hr}$ in the malnourished embryos, thus indicating about $3 \mathrm{hr}$ of prolongation in the latter. DNA synthetic time was about $6.5 \mathrm{hr}$ in the control and $7.0 \mathrm{hr}$ and $7.0 \mathrm{hr}$ in the two malnourished groups. The postduplication time was about $2.5 \mathrm{hr}$ in the control and $3.0 \mathrm{hr}$ and $3.5 \mathrm{hr}$ in the malnourished. The preduplication time was about $8.8 \mathrm{hr}$ in the control and $10.6 \mathrm{hr}$ and $\mathbf{1 0 . 3} \mathrm{hr}$ in the malnourished.
\end{abstract}

\section{Speculation}

Most neurons in the mouse cerebrum are produced at the matrix layer, where active cellular proliferation takes place from the 10th to the 16th days of gestation. Malnutrition during this period caused about $14 \%$ prolongation of the generation time of the matrix cell, the precursor of neurons, thus causing a decrease in neuron production. Malnutrition during the first and second trimester may cause similar results in the human embryo.

There is increasing evidence that infants who are born with intrauterine growth retardation (IUGR) have a higher incidence of central nervous system problems than infants born with appropriate growth for gestational age $(6,7,28)$. This evidence has also been confirmed by our retrospective study on the causes of microcephaly, in which as many as 36 cases of 140 microcephalics $(26 \%)$ were the products of IUGR (23). Severe maternal toxemia, metabolic and endocrinologic disorders, and chronic renal disease of the mother, placental anomalies, and fetal infections are the main etiologic factors of IUGR $(12,17,20,21)$. Most of these factors also often give rise to nutritional deprivation for the infant either directly or indirectly.

Recently many reports have been published on the effects of maternal undernutrition on the brain development of the fetus $(5,20,29)$. Most of these are in agreement with the proposition that maternal undernutrition inhibits the increase of cell number in the brain of fetuses. However, questions have arisen on what kind of cells -i.e., neuron, glia, or vascular epithelial cells - and on which parts of the cell are most susceptible to malnutrition, since most results have been obtained biochemically by determining the DNA content in the cerebrum and cerebellum as a whole, after homogenization.

This experiment was undertaken as an effort to study the effect of maternal protein malnutrition and protein-calorie malnutrition on the proliferative activity of the matrix cell, the precursor of neurons, at the matrix layer of the embryonic mouse cerebrum by means of tritiated thymidine autoradiography.

\section{MATERIALS AND METHODS}

Forty-five ICR-JCL strain (31) pregnant mice were used in this experiment. The female mouse was considered to be at day 1 of gestation when the vaginal plug was found. Fifteen pregnant mice were fed the normal diet $(25.5 \mathrm{~g}$ protein and $352 \mathrm{cal}$ energy/100 g) (31) ad libitum from day 1 to day 16 of gestation, and served as the control. Another 15 pregnant mice were fed the normal diet ad libitum during the first 7 days and then placed on a low protein diet $(0.7 \mathrm{~g}$ protein and $369 \mathrm{cal}$ energy/100 g) (31) until the 16 th day of gestation. The remaining 15 pregnant mice were fed the normal diet ad libitum during the first 7 days, and then the diet was restricted to one-third of the normal daily intake, i.e., $2.5-2.8 \mathrm{~g} / \mathrm{day} / \mathrm{animal}$.

On the 16 th day of gestation, all pregnant mice in each group were injected intraperitoneally with $7 \mu \mathrm{Ci} / \mathrm{g}$ body weight $\left[{ }^{3} \mathrm{H}\right]$ thymidine (specific activity $6.7 \mathrm{Ci} / \mathrm{mM}$ ) (32). The embryos were delivered by cesarian section under anesthesia at $1,2,3,4$, $6,8,10,12,14,16,18,20,22,24$, and $26 \mathrm{hr}$ after $\left[{ }^{3} \mathrm{H}\right]$ thymidine injection. After $24 \mathrm{hr}$ of fixation in Bouin's solution, the embryos were weighed and then the brains were detached. The brains were embedded in paraffin and sectioned serially in a coronal plane at $5 \mu \mathrm{m}$. Sections through the midthalamus were coated with Sakura NR-M2 dipping film (33) and exposed at $5^{\circ}$. After 4 weeks of exposure, the sections were developed for $5 \mathrm{~min}$ and were then stained with hematoxylin and 
eosin. In the autoradigraphs, cells with more than 5 reduced silver grains on the nucleus were considered to be labeled.

On the autoradiographic sections of each group of embryos which were killed 1 and $2 \mathrm{hr}$ after the $\left[{ }^{3} \mathrm{H}\right]$ thymidine injection, the percentage of labeled nuclei (labeling index) was calculated at the matrix layer surrounding the lateral ventricles by two researchers independently.

To calculate the generation time of the matrix cell and the times needed for various phases in the generation cycle, the mean percentage of labeled mitoses was plotted against the time after the $\left[{ }^{3} \mathrm{H}\right]$ thymidine injection as we reported previously (24). The percentage of labeled mitoses was obtained by counting more than $\mathbf{3 0 0}$ mitoses in the matrix layer of the parietal cortex in each embryo. The autoradiograph of each brain was examined independently by two researchers. The Student $t$-test was used for all statistical comparisons.

\section{RESULTS}

There was no significant difference between the control group (9.6 \pm 2.4 embryos), the PM group (10.4 \pm 2.1 embryos), and the PCM group $(10.2 \pm 1.9$ embryos) as to mean litter size $(9.6$ versus $10.4, t=0.827, P>0.4 ; 9.6$ versus $10.2, t=0.859, P>$ $0.3)$. There was, however, a significant difference in mean body weight between control $(0.40 \pm 0.05 \mathrm{~g}), \mathrm{PM}(0.32 \pm 0.06 \mathrm{~g})$, and PCM groups $(0.34 \pm 0.04 \mathrm{~g})(0.40$ versus $0.32, t=3.700$, $P<0.001 ; 0.40$ versus $0.34, t=3.286, P<0.005)$.

The cerebral cortex at this stage of development consisted of three different layers-i.e., from the outer to the inner-the cortical plate, the migratory zone, and the matrix layer (Fig. 1). Figure 2 shows the width of each layer measured at the parietal cortices of the control, PM, and PCM embryos. There was no difference in width of the migratory zone between the control and the malnourished group. However, the width of the cortical plate of the malnourished embryos (35.33 $\mu \mathrm{m}$ in PM and 30.00 $\mu \mathrm{m}$ in PCM) was significantly smaller than that of the control $(65.33 \mu \mathrm{m})(P<0.001)$. The width of the matrix layer in PM $(78.00 \mu \mathrm{m})$ was significantly smaller $(t=6.980, P<0.001)$, but that of PCM $(96.00 \mu \mathrm{m})$ showed no significant difference $(t=1.633, P>0.1)$ from the control $(108.00 \mu \mathrm{m})$.

One or $2 \mathrm{hr}$ after injection of $\left[{ }^{3} \mathrm{H}\right]$ thymidine, labeled nuclei were found almost exclusively at the deeper part of the matrix layer (Figs. 1 and $3 A$ ). A few labeled nuclei were also found in the migratory zone. However, any nuclei in the cortical plate were not labeled. The mean labeling indices calculated at the matrix layers in the cerebrums of each group of fetuses killed 1

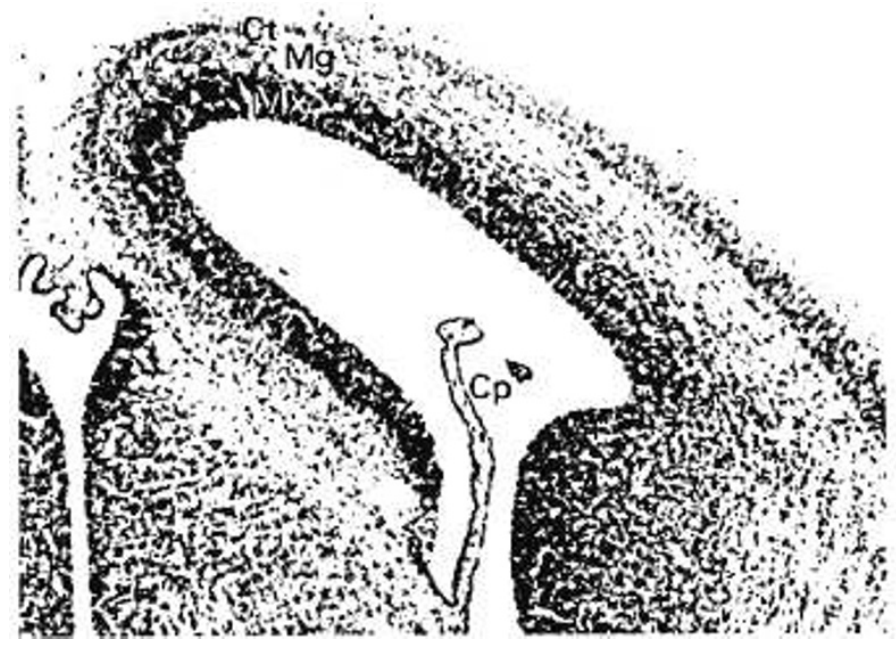

Fig. 1. Autoradiograph of cerebral cortex of 16-day-old malnourished fetus treated with $\left[{ }^{3} \mathrm{H}\right]$ thymidine $2 \mathrm{hr}$ before death. Labeled cells are localized exclusively at the matrix layer $(\mathrm{Mx}) . \mathrm{Ct}$ : cortical plate, $\mathrm{Mg}$ : migratory zone, $\mathrm{Cp}$ : choroid plexus. Magnification $\times 45$.

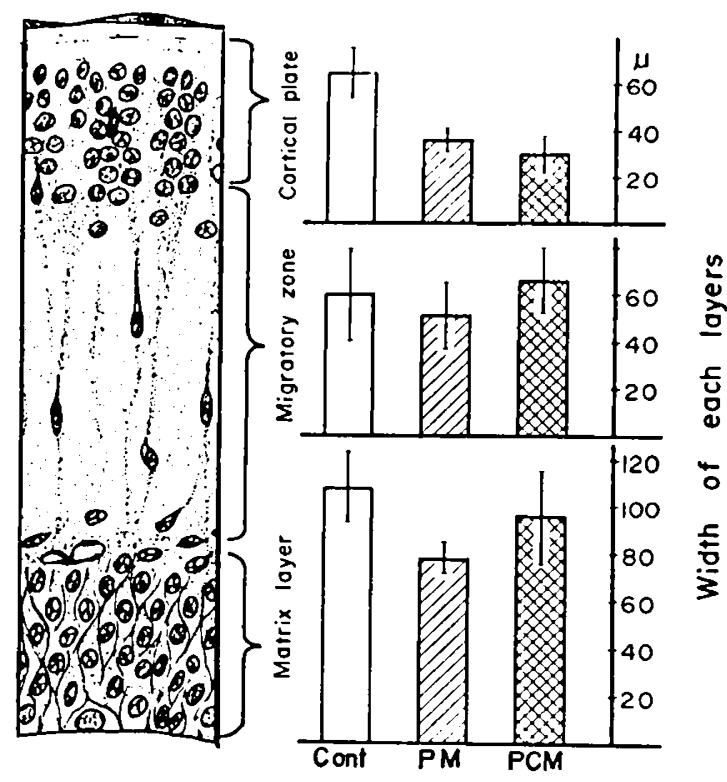

Fig. 2. Width of the matrix layer, migratory zone, and cortical plate at parietal region of cerebral cortices of the control and malnourished fetuses. Cont: control, PM: protein malnutrition, PCM: protein-calorie malnutrition.

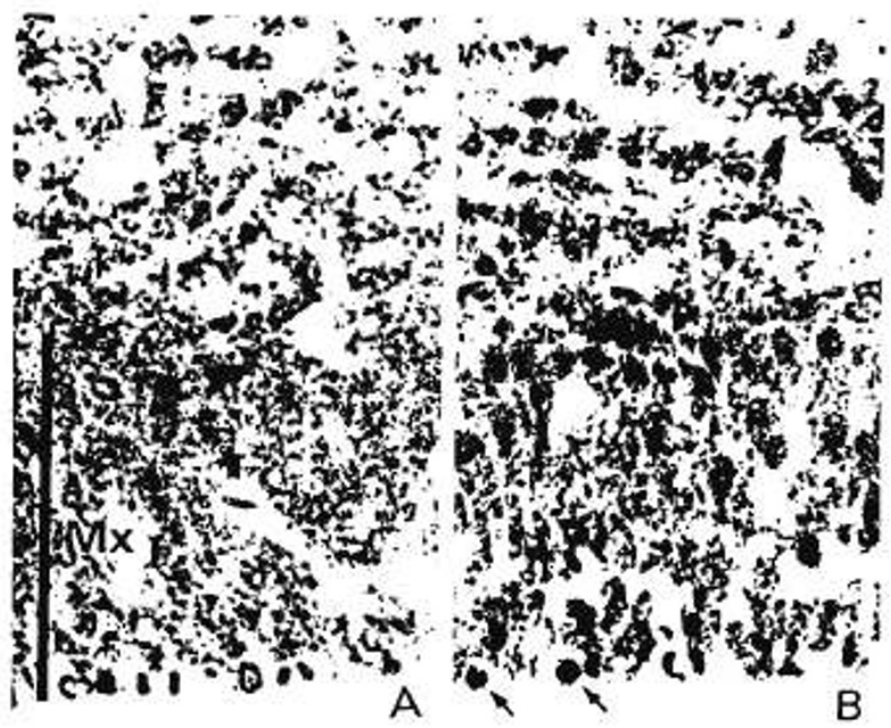

Fig. 3. A : autoradiograph of cerebral cortex in 16-day-old proteinmalnourished fetus treated with $\left[{ }^{3} \mathrm{H}\right]$ thymidine $1 \mathrm{hr}$ before death. Labeled nuclei are found at the deeper part of the matrix layer. All mitoses are free from radioactivity. Magnification $\times 350 . B$ : autoradiograph of cerebral cortex in 16-day-old protein-malnourished fetus, killed $3 \mathrm{hr}$ after $\left[{ }^{3} \mathrm{H}\right]$ thymidine injection. Labeled nuclei are disperesed throughout the matrix layer and many mitoses show radioactivity (arrow). Magnification $\times 350$

or $2 \mathrm{hr}$ after the $\left[{ }^{3} \mathrm{H}\right]$ thymidine injection were $36 \pm 3.6 \%$ in the control, $39 \pm 3.7 \%$ in the PM, and $35 \pm 3.5 \%$ in the PCM group. This difference in the labeling indices obtained in each group was statistically insignificant $(P>0.5)$.

Figure 4 shows the percentage of labeled mitoses plotted against the time after the $\left[{ }^{3} \mathrm{H}\right]$ thymidine injection. One and $2 \mathrm{hr}$ after the $\left[{ }^{3} \mathrm{H}\right]$ thymidine injection, most labeled nuclei were located at the deeper part of the matrix layer. There were only a few labeled mitoses throughout the entire surface of the lateral ventricles. Three hours after the $\left[{ }^{3} \mathrm{H}\right]$ thymidine injection, the percentages of labeled mitoses were $73.5 \%$ in the control, 
$46.0 \%$ in the PM (Fig. $3 B$ ), and $26.0 \%$ in the PCM embryos, respectively. When each group of embryos was examined $4 \mathrm{hr}$ after the $\left[{ }^{3} \mathrm{H}\right]$ thymidine injection, the percentage of labeled mitoses in the control embryos reached $100 \%$, and those of the malnourished were $95.5 \%$ and $95.2 \%$, respectively. These high percentage values of labeled mitoses were maintained in each group until $8 \mathrm{hr}$ after the injection of $\left[{ }^{3} \mathrm{H}\right]$ thymidine. Later than $8 \mathrm{hr}$ after the $\left[{ }^{3} \mathrm{H}\right]$ thymidine injection, the percentage of labeled mitoses decreased abruptly to reach its lowest value at $14 \mathrm{hr}$ after the injection in the control, and $18 \mathrm{hr}$ in both malnourished groups. Then the labeled mitoses increased again. The percentage of labeled mitoses in the control mice exceeded the $50 \%$ point again $22 \mathrm{hr}$ after the $\left[{ }^{3} \mathrm{H}\right]$ thymidine injection, and those of labeled mitoses in both malnourished groups exceeded this point again at $26 \mathrm{hr}$ after the injection. The generation time $\left(\mathrm{T}_{k}\right)$ of the matrix cells, which is equal to the distance between the $50 \%$ point on the first ascending curve $\left(a, a^{\prime}, a^{\prime \prime}\right)$ and that on the second ascending curve $\left(c, c^{\prime}, c^{\prime \prime}\right)$, is approximately $18.5 \mathrm{hr}$ in the control, $21.5 \mathrm{hr}$ in the PM, and $21.8 \mathrm{hr}$ in the PCM group, thus indicating about $3 \mathrm{hr}$ of prolongation in both malnourished groups. The DNA synthetic time (S), which is equal to the distance between the point $a, a^{\prime}$, or $a^{\prime \prime}$ and $b, b^{\prime}$ or $b^{\prime \prime}$, is about $6.5 \mathrm{hr}$ in the control and $7.0 \mathrm{hr}$ in both malnourished groups, thus showing about $0.5 \mathrm{hr}$ of prolongation in the latter. The postduplication time $\left(\mathrm{T}_{2}\right)\left(\mathrm{o}-\mathrm{a}, \mathrm{o}-\mathrm{a}^{\prime}, \mathrm{o}-\mathrm{a}^{\prime \prime}\right)$ was about $2.5 \mathrm{hr}$ in the control, $3.0 \mathrm{hr}$ in the PM, and $3.5 \mathrm{hr}$ in the PCM group. Since the mitotic index (MI) counted at the matrix layer was 3.7 $\pm 0.07 \%$ in the control, $4.2 \pm 0.10 \%$ in the PM, and $4.4 \pm$ $0.06 \%$ in the PCM, the time needed for mitosis $\left(\mathrm{T}_{\mathrm{m}}\right)$ was
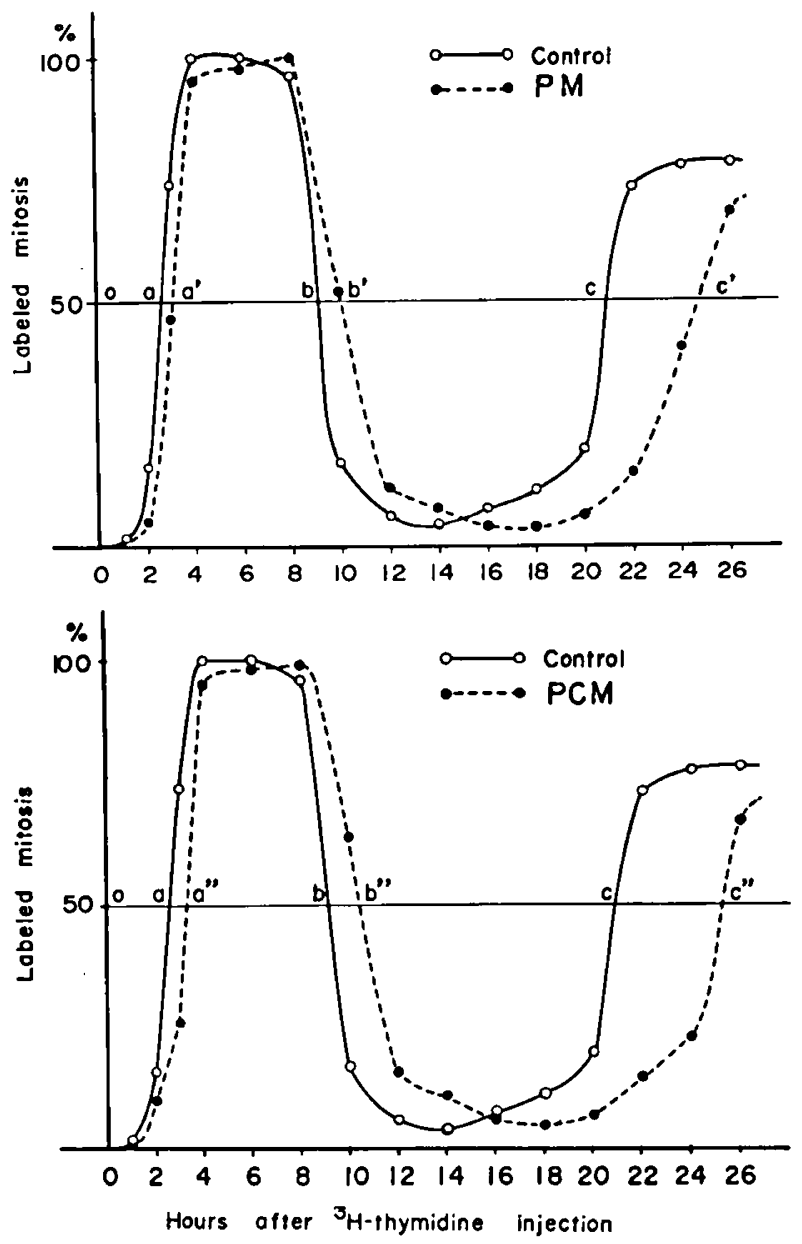

Fig. 4. Percentage of labeled mitoses in the matrix layer of the parietal cortex in 16-day-old control and malnourished fetuses plotted against the time after treatment with $\left[{ }^{3} \mathrm{H}\right]$ thymidine. calculated by the formula $\left(\mathrm{MI}=\mathrm{T}_{\mathrm{m}} / \mathrm{T}_{\mathrm{k}} \times 100\right)$ to be $0.7,0.9$, and $1.0 \mathrm{hr}$, respectively. The preduplication time $\left(\mathrm{T}_{1}\right)$ was about $8.8 \mathrm{hr}$ in the control, and $10.6 \mathrm{hr}$ and $10.3 \mathrm{hr}$ in the malnourished groups, thus indicating about $2 \mathrm{hr}$ of prolongation in the latter groups.

\section{DISCUSSION}

It has been clearly demonstrated by $\left[{ }^{3} \mathrm{H}\right]$ thymidine autoradiography that all neurons are produced at the matrix layer, where active cellular proliferation takes place, and then they migrate to destined positions in the brain $(3,4,9,24,25)$. Figure 5 shows the time of neuron origin in the central nervous system of the mouse, as has been reported by many investigators $(1-3,10,13,18,22,24-27)$. According to this figure, the period of malnutrition in the present experiment coincides with the period of neuron production in the cerebrum.

As shown in this experiment and also in many other reports $(8,14-16,19)$, the matrix cell shows particular patterns of cell proliferation kinetics. The nuclei of these cells synthesize DNA at the inner portion of the matrix layer and then move to the surface of the ventricles to undergo mitosis. After division of the matrix cells some of the daughter cells remain in the matrix layer for further proliferation, whereas others migrate out to become neurons. Hence, it may be conjectured that the matrix cell needs more materials and energy for cellular proliferation than any other cell in the cerebrum at this stage of development.

Both the PM and PCM, during the neurocytogenesis in the brain of the mouse embryo, were subject to about $3 \mathrm{hr}$ of prolongation of the generation time of the matrix cell. This prolongation of generation time consisted of a $0.5-\mathrm{hr}$ prolongation of the DNA synthetic time (S), a 0.5 -hr prolongation of the postduplication time $\left(\mathrm{T}_{2}\right)$, and a 2 -hr prolongation of the preduplication time $\left(T_{1}\right)$. The prolongation of the generation time $\left(T_{k}\right)$ of the matrix cell in the malnourished groups indicates fewer cell multiplications, and thus a lesser neuron production than that of the control. The result obtained in this experiment supports the biochemical data obtained by many investigators $(5,29,30)$, in which malnutrition during pregnancy causes a decrease of DNA content in the embryonic brain.

The labeling index obtained by direct counting should be equal to the value obtained by the formula (labeling index $=\mathrm{S} /$ $T_{k} \times 100$ ) when the tissue is composed of a homogenous cell population. The labeling indices calculated at the matrix layer in the control and malnourished groups were $36 \pm 3.59 \%$ in the former, and $39 \pm 3.74 \%$ and $35 \pm 3.51 \%$ in the latter, respectively, whereas the values obtained by the formula are $35.1 \%$ in the control and $32.6 \%$ and $32.1 \%$ in the malnourished groups. This discrepancy between the values obtained by direct counting and that obtained by the formula may have resulted from error in the direct counting of the labeling index, because it was very difficult to get reliable values on a $5-\mu \mathrm{m}$ section. Winick (29) reported that the labeling index counted around the lateral ventricles of 16-day rat embryos whose mothers had been fed low protein diets was about $5 \%$, whereas that of the agematched control was about $22 \%$. His data differ greatly from ours, even taking into account the difference of animal species. When these values are applied to the formula (labeling index = $\left.S / T_{k} \times 100\right)$, the generation time $\left(T_{k}\right)$ of the cells surrounding the lateral ventricles of the malnourished rat embryos should become more than 4 times longer than that of the control, otherwise the DNA synthetic time (S) would become much shorter in spite of the fewer materials for DNA synthesis. In the present experiment, in which pregnant mice were fed a diet with as little as one-tenth of the protein of that for the control group, the malnourished embryos contained as many heavily labeled cells as the control.

The width of the matrix layer in the PM was significantly smaller, but that of the matrix layer in the PCM was similar to 


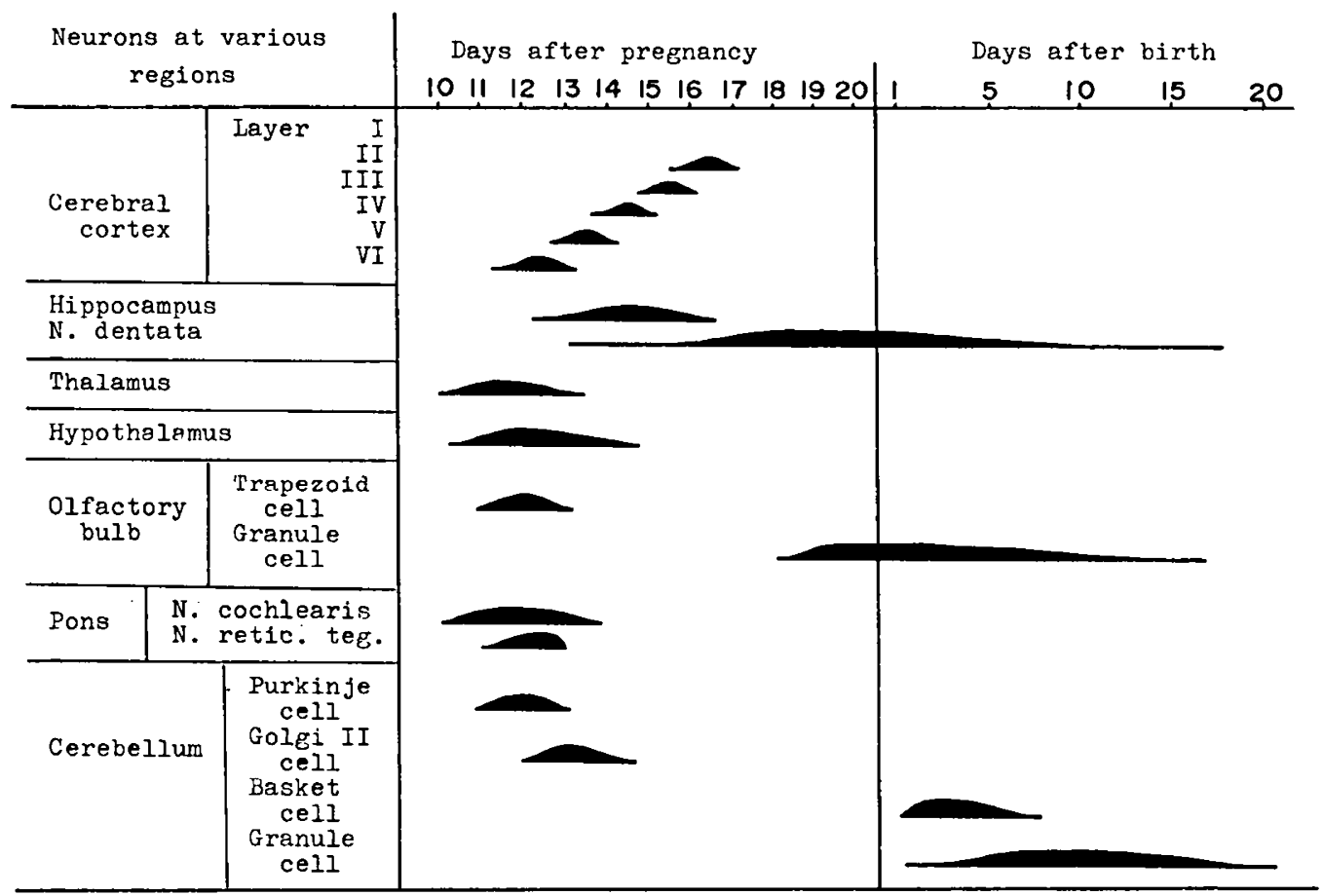

Fig. 5. Time of origin of various neurons in the mouse brain.

that of the controls. This data may seem to be paradoxic. As for the matrix layer, however, the minor difference of width itself has no great meaning. As reported by Hoshino et al. (11), for example, the width of the matrix layer of 10-day-old mouse embryos is smaller than that of 13-day-old embryos, but the proliferative activity of the former is about twice as great as the latter. Thus, the level of proliferative activity of the matrix cells is more significant in the matrix layer than the width of the layer. The significant difference between the control and the malnourished groups in the width of the cortical plates reflects very accurately the effects of malnutrition on the matrix layer, i.e., the lower proliferative activity, and thus the reduced production of cortical neurons in this layer.

\section{CONCLUSION}

Fifteen pregnant mice were fed either low protein diets or calorically restricted diets from the 8 th to the 16 th day of gestation, when $\left[{ }^{3} \mathrm{H}\right]$ thymidine was injected. The animals were killed at 1- or 2-hr intervals and coronal sections of the fetal brains were processed for autoradiography. DNA-synthesizing cells were found almost exclusively at the matrix layer surrounding the ventricular system. More than $30 \%$ of the matrix cells always synthesize DNA before cell division. The generation time calculated for the matrix cell was $21.5 \mathrm{hr}$ in protein-malnourished embryos and $21.8 \mathrm{hr}$ in protein-calorie-malnourished embryos, whereas that of the age-matched control was $18.5 \mathrm{hr}$, thus indicating about $3 \mathrm{hr}$ of prolongation in the former. This prolongation in the malnourished fetuses consisted mainly of a 2-hr prolongation of preduplication time $\left(T_{1}\right)$. DNA synthetic times did not differ much between the malnourished $(7.0 \mathrm{hr}$ and 7.0 $\mathrm{hr})$ and the control groups $(6.5 \mathrm{hr})$.

\section{REFERENCES AND NOTES}

1. Angevine, J. B.: Autoradiographic study of histogenesis in the area dentata of the cerebral cortex in the mouse. Anat. Rec., I48: 255 (1964).

2. Angevine, J. B.: Time of neuron origin in the hippocampal region. Exp. Neurol. Suppl., 2: 1 (1965).
3. Angevine, J. B., and Sidman, R. L.: Autoradiographic study of cell migrations during histogenesis of cerebral cortex in the mouse. Nature, 192: 766 (1961).

4. Berry, M., and Rogers, A. W.: The migration of neuroblasts in the developing cerebral cortex. J. Anat., 99: 691 (1965).

5. Chase, H. P., Dabiere, C. S., and Welch, N. N.: Intra-uterine undernutrition and brain development. Pediatrics, 47: 491 (1971).

6. Collins, E., and Turner, G.: The importance of the "small-for-date" baby to the problem of mental retardation. Med. J. Aust., 2: 313 (1971).

7. Drillien, C. M.: The small-for-date infant: Etiology and prognosis. Pediat. Clin. N. Amer., 17: 9 (1970)

8. Fujita, S.: Kinetics of cellular proliferation. Exp. Cell Res., 28: 52 (1962)

9. Fujita. S.: Analysis of neuron differentiation in the central nervous system by tritiated thymidine autoradiography. J. Comp. Neurol., 122: 301 (1964).

10. Hinds, J. W.: Autoradiographic study of histogenesis in the mouse olfactory bulb. I. Time of origin of neurons and neuroglia. J. Comp. Neurol., 134: 287 (1968).

11. Hoshino, K., Matsuzawa, T., and Murakami, U.: Characteristics of the cell cycle of matrix cells in the mouse embryo during histogenesis of telencephalon. Exp. Cell Res., 77: 89 (1973).

12. Hughes, W. T.: Infections and intrauterine growth retardation. Pediat. Clin. N. Amer., 17: 119 (1970).

13. Johnston, A., and Angevine, J. B.: Autoradiographic study of neuron origin in the diencephalon in the mousc. Anat. Rec., 154: 363 (1966).

14. Kauffman, S. L.: An autoradiographic study of the generation cycle in the tenday mouse embryo neural tube. Exp. Cell Res., 42: 67 (1966).

15. Langman, J., Guerrant, R. L., and Freeman, B. C.: Behavior of neuroepithelial cells during closure of the neural tube. J. Comp. Neurol., 127: 399 (1966).

16. Langman, J., and Welch, G. W.: Excess vitamin A and development of the cerebral cortex. J. Comp. Neurol., 131: 15 (1967).

17. McMillan, D. R.: Endocrine influences on fetal growth. Pediat. Clin. N. Amer., 17: 111 (1970).

18. Miale, I. L., and Sidman, R. L.: An autoradiographic analysis of histogenesis in the mouse cerebellum. Exp. Neurol., 4: 277 (1961).

19. Sauer, M. E., and Walker, B. E.: Radioautographic study of interkinetic nuclear migration in the neural tube. Proc. Soc. Exp. Biol. Med., 101: 557 (1959).

20. Schulte, F. J, Schrempf, G., and Zinge, G.: Maternal toxcemia, fetal malnutrition and motor behavior of the newborn. Pediatrics, 48: 871 (1971).

21. Shanklin, D. R.: The influence of placental lesions on the newborn infant. Pediat. Clin. N. Amer., 17: 25 (1970).

22. Shimada, M.: Cytokinetics and histogenesis of early postnatal mouse brain as studied by ${ }^{3} \mathrm{H}$-thymidine autoradiography. Arch. Hist. Jap., 26: 413 (1966).

23. Shimada, M., Yamano, T., Morikawa, Y., Kasubuchi, Y., Wakaizumi, S. and Kusunoki, T.: Retrospective study on the causes of microcephaly. Acta Paediat. Jap., 16: 46 (1974) 
24. Shimada, M., and Langman, J.: Cell proliferation, migration and differentiation in the cerebral cortex of the golden hamster. J. Comp. Neurol., 139 $227(1970)$.

25. Shimada, M., and Nakamura, T.: Time of neuron origin in mouse hypothalamic nuclei. Exp. Neurol. 41: 163 (1973).

26. Taber-Pierce, E.: Histogenesis of the nuclei griseum pontis corporis pontobulbaris and reticularis tegmenti pontis (Bechterew) in the mouse: An autoradiographic study. J. Comp. Neurol., 126: 219 (1966).

27. Taber-Pierce, E.: Histogenesis of the dorsal and ventral cochlear nuclei in the mouse: An autoradiographic study. J. Comp. Neurol., 131: 27 (1967).

28. Warkany, J., Monroe, B. B., and Sutherland, B. S.: Intrauterine growth retardation. Amer. J. Dis. Child., 102: 249 (1961)
29. Winick, M.: Cellular growth in intrauterine malnutrition. Pediat. Clin. N. Amer., 17: 69 (1970).

30. Zamenhof, S., van Marthens, E., and Margolis, F. L.: DNA (cell number) and protein in neonatal brain: Alteration by maternal dietary protein restriction. Science, $160: 322$ (1968)

31. Nippon Clea Co. Ltd., Osaka, Japan.

32. Japan Isotope Corp., Tokyo, Japan.

33. Sakura Film Co. Ltd., Osaka, Japan.

34. Requests for reprints should be addressed to: M. Shimada, M.D., Department of Pediatrics, Shiga Medical College, Seta, Otsu-shi 520-521 (Japan).

35. Received for publication July 10,1976

36. Accepted for publication October $27,1976$.
Asthma chemotaxis

eczema
HLA-B12 neutrophil(s) skin infections

\title{
A Familial Defect of Neutrophil Chemotaxis with Asthma, Eczema, and Recurrent Skin Infections
}

\author{
JERRY C. JACOBS ${ }^{(28)}$ AND MICHAEL E. NORMAN \\ Departments of Pediatrics, College of Physicians and Surgeons, Columbia University, New York, and the University \\ of Pennsylvania, Philadelphia and Babies Hospital, the Children's Medical and Surgical Center, New York,
} New York, USA

\section{Summary}

A defect in chemotaxis of peripheral blood polymorphonuclear leukocytes (PMN's) was demonstrated in both parents and three of four children in a single family afflicted with varying degrees of respiratory allergy, unusual onset of severe eczema in the first month of life, and recurrent bacterial skin infections. Of great interest was the identification of HLA-B12 at the B locus in all affected members but not in the unaffected child. The two children known since infancy to be most severely affected with eczema and recurrent infections are HLA identical and homozygous for HLA-B12. The child without eczema and infections had an intermediate cellular chemotactic defect most apparent on kinetic studies.

\section{Speculation}

Recently, several familial defects of neutrophil chemotaxis have been reported in association with syndromes of recurrent bacterial infections, reaginic hypersensitivity, and/or clinical atopy. Our studies extend these observations by describing the possible genetic relationships between atopy (e.g., eczema) chemotactic defects, and the HLA system. Future studies in this field should examine the association between chemotactic defects and the HLA system, and the requirements of both atopy and chemotactic defects to produce recurrent infections.

Migration of leukocytes to sites of inflammation and infection involves a number of complex interrelating processes which presently are poorly understood. However, each definition of a variant from normal, each "experiment of nature," may contribute to an increased understanding of these basic mechanisms and, ultimately, to more effective relief of symptoms.

Hill and Quie (6) first described a defect in neutrophil chemotaxis in three unrelated children with eczema, recurrent bacterial infections, and increased serum immunoglobulin E (IgE) levels. We now report our findings of a cellular chemotactic defect in the neutrophils of five of six family members, followed for 11 years and studied repeatedly during a 2.5-year period, who display a pattern of unusually severe chronic eczema, asthma, and recurrent bacterial skin infections, all starting in the first month of life. The repetitive pattern of onset of a severe dermatitis in the first month of life suggested the possibility of an immunologic deficiency. In this family, phenotypic expression of the anomaly is associated with the presence of the histocompatibility antigen HLA-B12.

\section{CASE REPORTS}

CASE 1 (FW)

The 46-year-old father of the four children reported below has suffered from asthma and severe eczema with lichenification all of his life. During childhood the eczema was frequently infected. He has been otherwise healthy.

\section{CASE $2(D W)$}

The 38-year-old mother of the four children reported below has suffered from asthma and mild atopic dermatitis all her life. She has been otherwise healthy. Her marriage to $F W$ is not consanguinous.

\section{CASE 3 (AW)}

This 16-year-old daughter of cases 1 and 2 has had eczema with frequent staphylococcal superinfection since early infancy. Her skin is greatly lichenified. At age 15 she had osteomyletis (presumed to be staphylococcal and treated as such) of the left tibia. Over the years she has had a number of hospitalizations for asthma, and many episodes of impetiginous superinfection of her eczema. Growth and development are normal.

\section{CASE $4(R W)$}

This 11-year-old son of cases 1 and 2 has had eczema and asthma since early infancy with recurrent episodes of impetigi- 